\title{
Life-history traits of the invasive fish Gambusia holbrooki in saline streams (SE Iberian Peninsula): Does salinity limit its invasive success?
}

\author{
A. Ruiz-Navarro*, R. Moreno-Valcárcel, M. Torralva, F. J. Oliva-Paterna \\ Departamento de Zoología y Antropología Física, Universidad de Murcia, 30100 Murcia, Spain
}

\begin{abstract}
Knowledge of the adaptive ability of the highly invasive fish Gambusia holbrooki to new habitats is essential for determining its invasion potential. Our main objective was to assess the life-history of G. holbrooki in saline streams by studying its abundance, size and age structure, growth and condition. Two populations inhabiting similar streams of different salinity in the southeastern Iberian Peninsula were monitored over a 2 yr period. In both populations, the lifehistory of the species was characterized by a short life span, a long recruitment period with a massive emergence of young-of-the-year and fast growth of individuals during the first months of their lives. The species showed a less intense recruitment (6.9\% of juveniles vs. $46.4 \%$ during the recruitment period) and an earlier end of the recruitment period (at least $2 \mathrm{mo}$ ) in the hypersaline system, although abundance, hepatic condition and female somatic condition were higher. In addition, temporary increases in salinity diminished population abundance, recruitment, and somatic and hepatic condition. Both populations showed similar seasonal abundance variation patterns, population structures, growth rates, and somatic and hepatic condition cycles. Other environmental factors independent of salinity could have influenced the differentiation in lifehistory of the species between populations, thus disguising direct relationships between salinity and life-history. However, the studied parameters show that G. holbrooki presents a great ability to adapt to lotic systems with high and different levels of salinity.
\end{abstract}

KEY WORDS: Gambusia holbrooki $\cdot$ Invasive success $\cdot$ Salinity $\cdot$ Population dynamics $\cdot$ Growth Condition

Resale or republication not permitted without written consent of the publisher

\section{INTRODUCTION}

Gambusia holbrooki Girard is a poeciliid fish introduced into fresh and saline aquatic systems worldwide as a mosquito control agent. The 2 closely related species, G. holbrooki and G. affinis, are native only to North America, but together are considered among the world's 100 worst invasive alien species by the Global Invasive Species Programme (Lowe et al. 2000). They are the most abundant, widespread freshwater fish in the world, which is a consequence of their tolerance of a wide range of environmental conditions and their high reproductive potential (Pyke 2005, 2008).
Increasing our knowledge of the life-history characteristics of invasive fish species is necessary for the development of effective management and control programmes (Ribeiro et al. 2008), while such species also represent a great opportunity to study fish ecology and evolution at unusual spatial and temporal scales (Rice \& Sax 2005). Moreover, identification of the life-history traits that are most relevant for the success of an exotic species is fundamental for understanding the invasive process and for predicting the success of new or potential invaders and invasions. Although the biology and ecology of Gambusia holbrooki have been widely studied in its native distribution range (Pyke 2005), the biological traits of this 
species have been less studied than those of $G$. affinis in exotic populations (Haynes \& Cashner 1995). In the Mediterranean Basin there has been no previous study of 2 complete annual cycles of a G. holbrooki population.

It is suggested that salinity might limit the invasive success of Gambusia holbrooki, which would displace native fish fauna to saltier waters (Nordlie \& Mirandi 1996, Doadrio 2002, Alcaraz et al. 2008). However, no studies have addressed the influence of water salinity on the temporal cycle of G. holbrooki biology. Alcaraz \& García-Berthou (2007) examined differences in the life-history traits of G. holbrooki inhabiting systems distributed in a gradient of up to $23 \mathrm{~g} \mathrm{l}^{-1}$ water salinity, although they used a non-temporal approach. Salinity is an important stress factor in G. holbrooki population viability, although experimental studies on the salinity tolerance of G. holbrooki and G. affinis (hereafter Gambusia spp. where both are referred to together) (Chervinski 1983, Nordlie \& Mirandi 1996) have reported their ability to survive in waters of $58.5 \mathrm{~g} \mathrm{l}^{-1}$ salinity for $30 \mathrm{~d}$. The populations established in the extreme habitats of the species distribution area are expected to express special life-history patterns because they are exposed to the limits of the conditions tolerated by the species (Beaudouin et al. 2008). Records of G. holbrooki in eusaline or hypersaline waters ( $>30 \mathrm{~g} \mathrm{l}^{-1}$; sensu Cowardin et al. 1979) are scarce (Alcaraz \& García-Berthou 2007). However, several viable populations of G. holbrooki in aquatic habitats of over $30 \mathrm{~g} \mathrm{l}^{-1}$ salinity have been observed in wetlands of the south of the Iberian Peninsula (e.g. Santa Pola, Mar Menor, Doñana; F. Oliva-Paterna unpubl. data).

The present 2 yr study examined the annual cycle of 2 populations from the most arid zone of the Gambusia holbrooki European distribution range. These populations inhabited 2 Mediterranean watercourses, both presenting different levels of salinity, which provided a unique opportunity to increase knowledge of the effects of high salinity on life-history traits. Under the assumption that salinity causes environmental stress, the specific objectives of this study were to (1) provide information about the lifehistory traits of $G$. holbrooki in semiarid saline systems and (2) compare the biological traits of the species between these 2 systems, which are basically differentiated by salinity levels. We hypothesized that G. holbrooki might adapt to mesosaline and hypersaline aquatic systems, displaying life-history traits in the two systems that differed from each other as well as from those displayed in freshwater habitats. Because the invasive success of G. holbrooki seems to be limited by water salinity, understanding its biology in saline habitats has important management implications for control programmes of this invasive species.

\section{MATERIALS AND METHODS}

\section{Study area}

The studied populations inhabited 2 Mediterranean streams (Chicamo and Rambla Salada) with similar hydrological regimes located in the sedimentary Fortuna-Abanilla ecological sector (Vidal-Abarca et al. 1990) belonging to the Segura River basin (SE Iberian Peninsula). Both aquatic systems are classified as semiarid streams, a term applied to streams in regions where the water balance is negative and environmental stress is variable and unpredictable (Vidal-Abarca et al. 1992). Mean annual precipitation in the study area is $~ 200$ to $300 \mathrm{~mm}$, mainly concentrated in spring and autumn, occasionally producing floods. Apart from floodings, average flow in both watercourses is usually less than $15 \mathrm{l} \mathrm{s}^{-1}$ (VidalAbarca et al. 2000, Gutiérrez-Cánovas et al. 2009) and the streams are regulated by dams or diversion channels in their lower sections.

Chicamo is a fourth-order stream, with intermittent surface water flow in approximately one-third of its $59.4 \mathrm{~km}$ total length. Chicamo water is mesosaline (sensu Cowardin et al. 1979; $7.6 \mathrm{~g} \mathrm{l}^{-1}$ mean salinity, Vidal-Abarca et al. 2000). However, water close to the source presents salinity values lower than $1.4 \mathrm{~g} \mathrm{l}^{-1}$ and salt concentration increases progressively downstream. Samplings were conducted in the first $150 \mathrm{~m}$ of the stream (permanent surface water flow). Aquatic primary producers in the sampling site include the macrophyte Chara vulgaris (mainly in pools), an extensive diatom assemblage on fine sediments, and epilithic periphyton, although in spring filamentous green algae tend to predominate (Martínez et al. 1998, Velasco et al. 2003). During the study, G. holbrooki co-existsed in Chicamo with the fish species Luciobarbus sclateri (Günther, 1868) and Aphanius iberus (Valenciennes, 1846).

Rambla Salada is a third-order stream $11.5 \mathrm{~km}$ long with intermittent flow at its headwaters and short ephemeral tributaries. It is a hypersaline stream (i.e. mean salinity values from 47.5 to $76.4 \mathrm{~g} \mathrm{l}^{-1}$ in 2004), principally because of Miocene gypsiferous marls (Velasco et al. 2006). The samplings were carried out in a $150 \mathrm{~m}$-long stretch at the middle section of the stream (permanent waters), where the substrate is 
characterized by large deposits of silt covered by a biofilm of diatoms and cyanobacteria. Some areas are covered by the filamentous alga Cladophora glomerata and the angiosperm plant Ruppia maritima, which decreases in coverage in the most saline areas (Velasco et al. 2006, Gutiérrez-Cánovas et al. 2009). In the sampling stretches of both systems, shallow pools $(<70 \mathrm{~cm})$ and runs constitute the principal aquatic habitat. In Rambla Salada, Gambusia holbrooki is the only fish species. Since the 1980s, an agricultural diversion channel that crosses over the Rambla Salada stream has suffered cracks at least once a year (Velasco et al. 2006), leading to moderate discharges (not as floods) of freshwater into the stream. These freshwater inputs have produced temporary salinity decreases to mesosaline conditions.

\section{Sampling methods}

From November 2005 to December 2007, a total of 60 samplings were carried out at least fortnightly during the reproductive period of Gambusia holbrooki (April-October; A. Ruiz-Navarro unpubl. data) and monthly during the rest of the year. Sampling consisted of a combined process of sieving (quadrangular hand nets $40 \times 40 \mathrm{~cm}, 1 \mathrm{~mm}$ mesh size) for 20 to $30 \mathrm{~min}$ and setting 20 minnow traps $(30 \mathrm{~mm} \varnothing, 1 \mathrm{~mm}$ mesh size) uniformly distributed in each sampling stretch $(150 \mathrm{~m}$ long) for roughly $24 \mathrm{~h}$. Water temperature $\left({ }^{\circ} \mathrm{C}\right), \mathrm{pH}$ and salinity $\left(\mathrm{g} \mathrm{l}^{-1}\right)$ were registered by a multiparameter probe WTW- $400^{\circledR}$ on each sampling date.

Fish were anesthetized with benzocaine and fixed in neutralized formaldehyde $(10 \%)$. All the captured fish were measured (total length $L_{\mathrm{T}} \pm 1 \mathrm{~mm}$ ) and sexed (male, female or juveniles), based on sexually dimorphic external morphology and, when necessary, on gonad identification. Within $30 \mathrm{~d}$ of capture, a sample of 4562 individuals was dissected and the eviscerated mass $\left(M_{\mathrm{E}}, \pm 1 \mathrm{mg}\right)$ and hepatic mass $\left(M_{\mathrm{H}}, \pm 0.1 \mathrm{mg}\right)$ were recorded. From 940 females and 624 males, a sample of scales was taken for age determination.

\section{Data analysis}

To assess the relative abundances of Gambusia holbrooki, the total number of individuals caught only by minnow traps was counted and expressed as catch per unit effort (CPUE), 1 unit being a passive trap in place for $24 \mathrm{~h}$. The temporal pattern of CPUE was analysed by ANOVA (after $\log _{10}$ transformation of data).

Population structure was determined by means of modal progression analysis, using FiSAT II software (FAO ICLARM Stock Assessment Tools ver. 1.2.0). Firstly, with the length-frequency-based method described by Bhattacharya (1967), size groups presumed to represent cohorts or age classes in the length-frequency seasonal samples were identified. Secondly, the separation of the normally distributed components (NORMSEP subroutine) was accomplished, where the separation index (SI) must be $>2$ to provide meaningfully separated groups (Gayanilo et al. 1988). Age determination by scales made it possible to assign an age to each size group. The modal distributions of length-frequency data were studied separately over short periods of time (monthly and seasonal periods) to reduce the effects of seasonal growth. Such methods involving length-frequency distribution and/or modal progression can provide useful estimates of relative age and average growth of fish. The intensity of recruitment was assessed using the relative frequency of juveniles $\left(L_{\mathrm{T}}<20 \mathrm{~mm}\right)$.

Over a defined period of time, the specific growth rate $(g)$ (Wootton 1998) was calculated as $g\left(L_{\mathrm{T}}\right)=$ $\left[\log _{\mathrm{e}}\left(L_{\mathrm{Tf}} L_{\mathrm{Ti}}{ }^{-1}\right)\right] t^{-1}$, where $L_{\mathrm{Tf}}$ is the final $L_{\mathrm{T}}, L_{\mathrm{Ti}}$ is the initial $L_{\mathrm{T}}$ and $t$ is the time interval. Specific growth rate was expressed as percentage per unit time, i.e. $G\left(L_{\mathrm{T}}\right)=100 g\left(L_{\mathrm{T}}\right)$. Seasonal and monthly growth rates of each size group identified in the distributions of length-frequency data were calculated.

Temporal variations in somatic and hepatic conditions were studied by analysing the length-mass relationships. The adjustment for size variation in the data by regression-related techniques has been successfully used with analysis of covariance (ANCOVA) for the same species (Alcaraz \& GarcíaBerthou 2007). This method applies ANCOVA using $M_{\mathrm{E}}\left(\right.$ or $\left.M_{\mathrm{H}}\right)$ as the dependent variable and $L_{\mathrm{T}}$ as the covariate. A log transformation is made to obtain a linear relationship between $M_{\mathrm{E}}$ (or $M_{\mathrm{H}}$ ) and $L_{\mathrm{T}}$. The homogeneity of the regression coefficients (slopes) is tested with an ANCOVA that analyses the pooled covariate-by-factor interaction. If the covariate-by-factor interaction (homogeneity of slopes) is not significant ( $p>0.05)$, standard ANCOVA is applied to obtain predicted values that are fitted according to $L_{\mathrm{T}}$ (ANCOVA-adjusted $M_{\mathrm{E}}$ or $M_{\mathrm{H}}$ values). We also analysed bivariate relationships between environmental variables (log transformed) and species growth rate, somatic condition and hepatic condition, using Spearman's correlation coefficients. 


\section{RESULTS}

\section{Environmental variables of sampling sites}

Water temperature showed an annual pattern, with maxima $\left(24.6^{\circ} \mathrm{C}\right.$ in Chicamo; $29.9^{\circ} \mathrm{C}$ in Rambla Salada) in July-August and minima $\left(13.4^{\circ} \mathrm{C}\right.$ in Chicamo; $8.4^{\circ} \mathrm{C}$ in Rambla Salada) in January-February. The mean temperature was $19.3^{\circ} \mathrm{C}$ in Chicamo and $20.0^{\circ} \mathrm{C}$ in Rambla Salada. Mean salinity was $1.3 \mathrm{~g} \mathrm{l}^{-1}$ in Chicamo and remained stable throughout the study period, and $32.1 \mathrm{~g} \mathrm{l}^{-1}$ in Rambla Salada, where it underwent substantial variations because of the discharges of freshwater from the diversion channel (Fig. 1). Between autumn 2006 and spring 2007, this system received such freshwater discharges and, as a consequence, the lowest salinity level recorded during the study $\left(9.7 \mathrm{~g} \mathrm{l}^{-1}\right)$ was reached in May 2007. In summer 2007, the discharges ceased and salinity increased.

\section{Abundance}

A total of 24754 individuals of Gambusia holbrooki were captured (2235 specimens from Chicamo and 22519 from Rambla Salada) during the studied

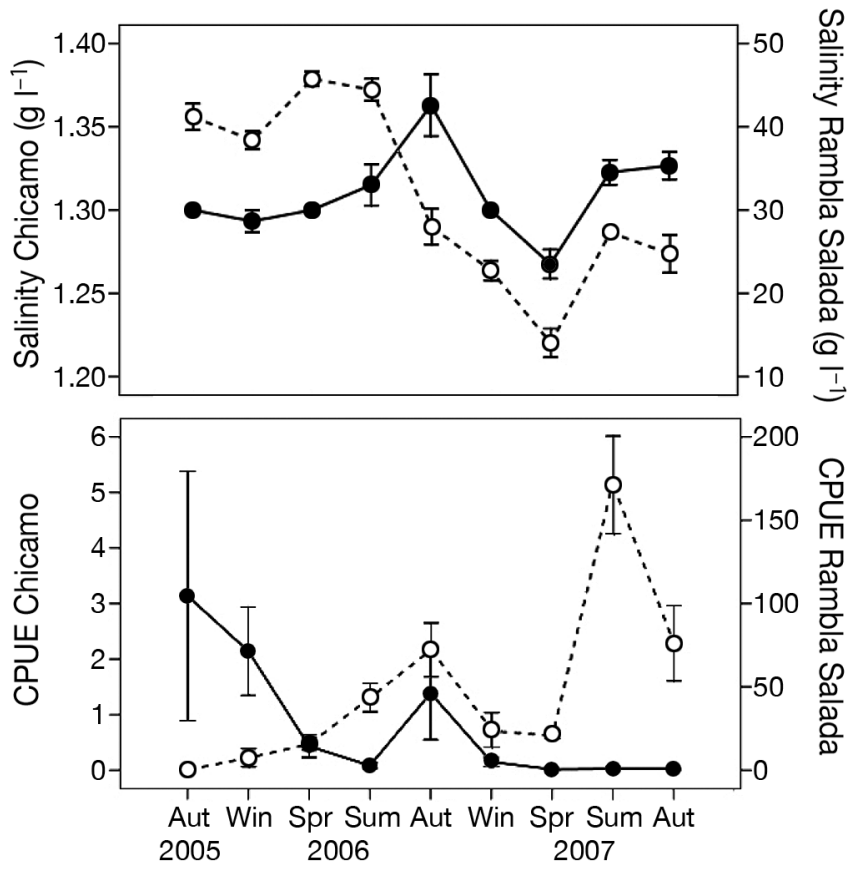

Fig. 1. Gambusia holbrooki. Temporal variation in salinity $\left(\mathrm{g} \mathrm{l}^{-1}\right)$ and relative abundance (catch per unit effort [CPUE]) of G. holbrooki at Chicamo (black circles) and Rambla Salada (white circles). Data are means \pm 1 SE. Aut: autumn; Win: winter; Spr: spring; Sum: summer period. Abundance was much higher in Rambla Salada (mean CPUE: $48.76 \pm 5.39$ ) than in Chicamo (mean CPUE: $0.60 \pm 0.19$ ). The temporal pattern of CPUE estimates for G. holbrooki in Chicamo showed a high degree of seasonal variation (ANOVA, season as a factor: $F_{8,604}=7.76, \mathrm{p}<0.001$ ), with maximum values in the autumns of 2005 and 2006 (Fig. 1). However, abundance was significantly lower for the second cycle of the study (autumn 2006-autumn 2007 ) than for the first (ANOVA: $F_{1,611}=14.41, \mathrm{p}<$ 0.001). Abundance also varied seasonally in Rambla Salada (ANOVA, season as a factor: $F_{8,654}=42.38$, $\mathrm{p}<0.001)$, and maximum values were reached in autumn 2006 and summer 2007 (Fig. 1). In this population, the CPUE values were significantly higher for the second cycle of the study (ANOVA: $F_{1,661}=55.24$, $\mathrm{p}<0.001)$. This result coincides with the significant decrease in water salinity during the second cycle, although no temporal correlation between abundance and salinity in Rambla Salada was found (Spearman's correlation of mean values: $r_{S}=-0.13$, $\mathrm{p}=0.633)$.

\section{Population structure and growth}

The modal progression analysis identified 3 to 5 size groups in females and 2 to 3 in males for each distribution of length-frequency seasonal data, in both populations (Table 1). The assignment of age to each size group showed the presence and temporal continuity of 2 annual sub-cohorts for males and females during the study period, and only one 2004 cohort for females. The 2 sub-cohorts joining the population in the same year were named A and B: sub-cohort A included fish born in the first part of the recruitment period and sub-cohort B included fish born in the second part of the recruitment period. The sub-cohorts were identified independently for each sex (e.g. 2006A males, 2006B males or 2005A females). Length-frequency histograms for consecutive summers showed that the population structure did not vary substantially. In Chicamo and Rambla Salada, Gambusia holbrooki presented similar age structures, characterized by longer-lived females and the fact that $0+$ individuals represented more than $75 \%$ of the stocks. Males disappeared from populations at the beginning of the reproductive period (spring-summer), no $2+$ males were captured, whereas females could be found up to the winter of the second year of their lives. The population structure was characterized by 4 age groups in Rambla Salada $(0+, 78.46 \% ; 1+, 19.83 \% ; 2+, 1.71 \%$; 
Table 1. Gambusia holbrooki. Size groups (rows) identified for each season from length-frequency data of males (+ juvenile individuals) and females (+ juvenile individuals) in the 2 populations studied. The separation index (SI) must be greater than 2 to provide meaningfully separated groups. Estimated age groups are confirmed by scale analysis. Total length $\left(L_{\mathrm{T}} ; \mathrm{mm}\right)$ data are given $\pm \mathrm{SD}$. $\mathrm{n}$ : number of individuals

\begin{tabular}{|c|c|c|c|c|c|c|c|c|}
\hline \multirow[b]{2}{*}{ Season } & \multirow[b]{2}{*}{$L_{\mathrm{T}}$} & \multicolumn{3}{|c|}{ - Chicamo } & \multirow[b]{2}{*}{$L_{\mathrm{T}}$} & \multicolumn{2}{|c|}{ Rambla Salada } & \multirow[b]{2}{*}{$\mathrm{n}$} \\
\hline & & SI & Age & $\mathrm{n}$ & & SI & Age & \\
\hline \multicolumn{9}{|l|}{ Males } \\
\hline \multirow[t]{2}{*}{ Autumn 2005} & $18.00^{\mathrm{a}}$ & & $0+$ & 1 & $21.72 \pm 1.75$ & - & $0+$ & 85 \\
\hline & $29.35 \pm 3.10$ & - & $0+$ & 43 & $26.85 \pm 1.80$ & 2.89 & $0+$ & 249 \\
\hline \multirow{2}{*}{ Winter 2006} & $23.38 \pm 3.25$ & - & $0+$ & 86 & $26.20 \pm 2.06$ & - & $0+$ & 225 \\
\hline & $28.84 \pm 2.00$ & 2.08 & $0+$ & 62 & & & & \\
\hline \multirow[t]{3}{*}{ Spring } & $16.86 \pm 4.71$ & - & $0+$ & 41 & $17.06 \pm 1.99$ & - & $0+$ & 93 \\
\hline & $31.27 \pm 3.24$ & 3.63 & $1+$ & 133 & $27.19 \pm 1.79$ & 5.36 & $1+$ & 677 \\
\hline & & & & & $31.54 \pm 1.55$ & 2.60 & $1+$ & 123 \\
\hline \multirow[t]{3}{*}{ Summer } & $14.93 \pm 3.12$ & - & $0+$ & 101 & $18.49 \pm 4.32$ & - & $0+$ & 226 \\
\hline & $21.47 \pm 3.43$ & 2.00 & $0+$ & 135 & $24.33 \pm 1.97$ & 1.86 & $0+$ & 1035 \\
\hline & $31.00 \pm 1.42$ & 6.56 & $1+$ & 2 & $29.00 \pm 1.61$ & 2.61 & $1+$ & 32 \\
\hline \multirow[t]{2}{*}{ Autumn } & $16.60 \pm 2.34$ & - & $0+$ & 131 & $17.38 \pm 1.19$ & - & $0+$ & 134 \\
\hline & $27.25 \pm 2.42$ & 4.47 & $0+$ & 45 & $26.19 \pm 2.02$ & 5.49 & $0+$ & 990 \\
\hline \multirow{2}{*}{ Winter 2007} & $17.43 \pm 1.00$ & - & $0+$ & 14 & $17.46 \pm 1.00$ & - & $0+$ & 15 \\
\hline & $27.37 \pm 2.17$ & 6.27 & $0+$ & 48 & $26.61 \pm 1.78$ & 6.58 & $0+$ & 923 \\
\hline Spring & $13.96 \pm 2.71$ & - & $0+$ & 55 & $16.07 \pm 3.05$ & - & $0+$ & 329 \\
\hline & $24.68 \pm 1.33$ & 5.31 & $1+$ & 11 & $27.31 \pm 2.03$ & 4.43 & $1+$ & 1080 \\
\hline & $30.36 \pm 1.30$ & 4.32 & $1+$ & 13 & & & & \\
\hline Summer & $15.56 \pm 3.88$ & - & $0+$ & 158 & $16.85 \pm 2.64$ & - & $0+$ & 497 \\
\hline & $23.52 \pm 1.95$ & 2.73 & $0+$ & 25 & $23.02 \pm 1.68$ & 2.86 & $0+$ & 1266 \\
\hline & & & & & $28.43 \pm 2.10$ & 2.86 & $1+$ & 293 \\
\hline Autumn & $16.00 \pm 1.58$ & - & $0+$ & 13 & $17.22 \pm 1.59$ & - & $0+$ & 38 \\
\hline & $27.10 \pm 2.70$ & 5.19 & $0+$ & 9 & $25.77 \pm 2.01$ & 4.75 & $0+$ & 637 \\
\hline Females & & & & & & & & \\
\hline Autumn 2005 & $23.22 \pm 3.27$ & - & $0+$ & 104 & $24.21 \pm 2.45$ & - & $0+$ & 286 \\
\hline & $29.86 \pm 1.50$ & 2.78 & $0+$ & 17 & $32.41 \pm 5.86$ & 1.97 & $0+$ & 252 \\
\hline & $41.00 \pm 2.40$ & 5.71 & $1+$ & 7 & $40.47 \pm 2.19$ & 2.00 & $1+$ & 228 \\
\hline Winter 2006 & $21.90 \pm 3.35$ & - & $0+$ & 103 & $23.82 \pm 1.31$ & - & $0+$ & 42 \\
\hline & $30.84 \pm 2.33$ & 3.15 & $0+$ & 60 & $28.86 \pm 3.71$ & 2.01 & $0+$ & 112 \\
\hline & $38.71 \pm 1.63$ & 3.97 & $1+$ & 7 & $40.63 \pm 1.01$ & 4.99 & $1+$ & 6 \\
\hline Spring & $14.57 \pm 4.59$ & - & $0+$ & 39 & $16.06 \pm 3.66$ & - & $0+$ & 106 \\
\hline & $33.78 \pm 5.48$ & 3.82 & $1+$ & 119 & $30.25 \pm 5.90$ & 2.97 & $1+$ & 375 \\
\hline & $40.31 \pm 1.56$ & 1.86 & $1+$ & 15 & $44.24 \pm 3.63$ & 2.94 & $1+$ & 331 \\
\hline & $42.25 \pm 2.06^{\mathrm{a}}$ & & $2+$ & 4 & $47.90 \pm 4.50^{\mathrm{a}}$ & & $2+$ & 13 \\
\hline & & & & & $49.00^{\mathrm{a}}$ & & $3+$ & 1 \\
\hline Summer & $15.15 \pm 3.71$ & - & $0+$ & 180 & $11.14 \pm 1.51$ & - & $0+$ & 24 \\
\hline & $26.20 \pm 4.16$ & 2.81 & $0+$ & 89 & $30.31 \pm 5.95$ & 5.14 & $0+$ & 2417 \\
\hline & $36.38 \pm 1.84$ & 3.39 & $1+$ & 15 & $49.37 \pm 2.46$ & 4.53 & $1+$ & 172 \\
\hline & $46.07 \pm 2.93$ & 4.06 & $1+$ & 6 & $54.33 \pm 0.58^{\mathrm{a}}$ & & $2+$ & 3 \\
\hline & $47.33 \pm 3.79^{\mathrm{a}}$ & & $2+$ & 3 & & & & \\
\hline Autumn & $17.64 \pm 3.08$ & - & $0+$ & 161 & $22.94 \pm 3.11$ & - & $0+$ & 1376 \\
\hline & $27.90 \pm 6.50$ & 2.14 & $0+$ & 110 & $33.65 \pm 4.64$ & 2.76 & $0+$ & 1314 \\
\hline & $45.31 \pm 1.00$ & 4.64 & $1+$ & 7 & $50.59 \pm 2.05$ & 5.06 & $1+$ & 9 \\
\hline & & & & & $52.00 \pm 1.41^{\mathrm{a}}$ & & $2+$ & 5 \\
\hline Winter 2007 & $23.24 \pm 3.56$ & - & $0+$ & 144 & $27.50 \pm 3.49$ & - & $0+$ & 1108 \\
\hline & $34.65 \pm 4.75$ & 2.75 & $0+$ & 34 & $34.85 \pm 2.99$ & 2.27 & $0+$ & 384 \\
\hline & $47.09 \pm 1.04$ & 4.30 & $1+$ & 2 & $40.46 \pm 2.13^{\mathrm{a}}$ & & $1+$ & 69 \\
\hline & $54.00^{\mathrm{a}}$ & & $2+$ & 1 & & & & \\
\hline Spring & $14.14 \pm 2.85$ & - & $0+$ & 57 & $17.39 \pm 4.72^{\mathrm{a}}$ & & $0+$ & 488 \\
\hline & $29.79 \pm 1.65$ & 6.96 & $1+$ & 5 & $28.65 \pm 3.09$ & - & $1+$ & 228 \\
\hline & $39.22 \pm 4.17$ & 3.24 & $1+$ & 34 & $37.06 \pm 5.05$ & 2.07 & $1+$ & 603 \\
\hline & $54.71 \pm 1.47$ & 5.49 & $2+$ & 6 & $49.02 \pm 3.15$ & 2.92 & $2+$ & 156 \\
\hline & & & & & $60.00^{\mathrm{a}}$ & & $3+$ & 1 \\
\hline Summer & $15.72 \pm 3.93$ & - & $0+$ & 164 & $20.83 \pm 1.07$ & - & $0+$ & 378 \\
\hline & $28.16 \pm 3.07$ & 3.55 & $0+$ & 35 & $26.12 \pm 5.53$ & 1.60 & $0+$ & 4438 \\
\hline & $36.99 \pm 2.61$ & 3.10 & $1+$ & 16 & $36.79 \pm 3.05$ & 2.49 & $1+$ & 237 \\
\hline & $52.00 \pm 6.48$ & 5.00 & $2+$ & 5 & $50.39 \pm 2.85$ & 4.61 & $2+$ & 196 \\
\hline Autumn & $19.12 \pm 3.68$ & - & $0+$ & 26 & $22.98 \pm 2.70$ & - & $0+$ & 782 \\
\hline & $33.69 \pm 2.82$ & 4.48 & $0+$ & 7 & $29.82 \pm 3.37$ & 2.25 & $0+$ & 1213 \\
\hline & & & & & $37.11 \pm 3.05$ & 2.27 & $1+$ & 651 \\
\hline & & & & & $49.37 \pm 2.98$ & 4.07 & $2+$ & 67 \\
\hline
\end{tabular}


Table 2. Gambusia holbrooki. Comparison of monthly growth rates $\left[G\left(L_{\mathrm{T}}\right)\right.$, where $L_{\mathrm{T}}$ is total length; $\%$, mean $\pm \mathrm{SD}$ ] of sub-cohorts (A and B) between Chicamo and Rambla Salada, and associated ANOVA results

\begin{tabular}{|c|c|c|c|c|c|c|}
\hline \multirow[b]{2}{*}{ Sex } & \multirow[b]{2}{*}{ Sub-cohort } & \multicolumn{2}{|r|}{$G\left(L_{\mathrm{T}}\right)$} & \multirow[b]{2}{*}{$F$} & \multicolumn{2}{|c|}{ ANOVA } \\
\hline & & Chicamo & Rambla Salada & & $\mathrm{df}$ & $\mathrm{p}$ \\
\hline \multirow[t]{6}{*}{ Male } & $2005 \mathrm{~A}$ & $0.67 \pm 7.20$ & $1.86 \pm 5.52$ & 0.11 & 1,11 & 0.742 \\
\hline & 2005B & $6.33 \pm 10.46$ & $3.43 \pm 6.11$ & 0.39 & 1,11 & 0.546 \\
\hline & $2006 \mathrm{~A}$ & $14.00 \pm 20.73$ & $9.00 \pm 12.32$ & 0.69 & 1,29 & 0.411 \\
\hline & 2006B & $8.00 \pm 12.44$ & $9.60 \pm 16.83$ & 0.05 & 1,15 & 0.834 \\
\hline & $2007 \mathrm{~A}$ & $27.25 \pm 21.23$ & $17.56 \pm 20.76$ & 0.90 & 1,15 & 0.357 \\
\hline & 2007B & 2.00 & $6.00 \pm 13.08$ & & & \\
\hline \multirow[t]{7}{*}{ Female } & 2004 & $1.67 \pm 1.53$ & $2.00 \pm 9.73$ & 0.00 & 1,10 & 0.955 \\
\hline & $2005 \mathrm{~A}$ & $2.67 \pm 8.50$ & $1.47 \pm 11.35$ & 0.10 & 1,27 & 0.760 \\
\hline & 2005B & $5.25 \pm 13.69$ & $3.59 \pm 15.35$ & 0.09 & 1,27 & 0.767 \\
\hline & $2006 \mathrm{~A}$ & $17.37 \pm 24.37$ & $10.50 \pm 16.15$ & 1.29 & 1,44 & 0.262 \\
\hline & $2006 B$ & $7.55 \pm 16.08$ & $9.73 \pm 18.86$ & 0.10 & 1,24 & 0.760 \\
\hline & $2007 \mathrm{~A}$ & $33.44 \pm 31.30$ & $20.15 \pm 24.85$ & 1.23 & 1,20 & 0.280 \\
\hline & 2007B & 22.00 & $15.00 \pm 18.13$ & & & \\
\hline
\end{tabular}

overlapped in length-frequency distributions, becoming indistinguishable (Fig. 2).

Females grew faster than males, both in their developing stage from juveniles to adults (ANOVA: $F_{1,44}=7.25, \mathrm{p}=$ $0.010)$ and during adulthood $\left(F_{1,52}=\right.$ $12.42, \mathrm{p}=0.001$ ). Furthermore, this fast growth of females lasted up to November-December, reaching higher mean $L_{\mathrm{T}}$ values than males (Fig. 2). At the end of this period, females of the first subcohort of the year (A) were longer than those of the second (B) (Fig. 2). Then, a period of very low or no growth began, which lasted until March of the next year, when fast growth began again and the 2 sub-cohorts overlapped in length-frequency distributions (Fig. 2).

and $3+, 0.01 \%)$ and 3 in Chicamo $(0+, 80.47 \% ; 1+$, $18.63 \%$; and $2+, 0.90 \%$ ).

In both systems, the modal progression analysis also identified a long recruitment period with a continuous presence of individuals shorter than $20 \mathrm{~mm}$ $L_{\mathrm{T}}$ from spring to autumn (Table 1). Although the catchability of specimens measuring less than $10 \mathrm{~mm}$ was practically zero, their presence was confirmed visually during the recruitment periods. Rambla Salada presented a lower proportion of juveniles $(6.9 \%)$ than Chicamo (46.4\%) (chi-square: $\chi^{2}=1607.27, \mathrm{p}<$ 0.001 ) and its recruitment period was shorter: November was the last month showing a significant presence of juveniles in Chicamo stream, whereas in Rambla Salada the presence of juveniles only lasted up to September 2006 and August 2007. Moreover, in Rambla Salada, the relative frequency of juveniles in May and June was lower in 2006 (7.6\%), when salinity was high, than in 2007 (15.9\%), which was characterized by low salinity $\left(\chi^{2}=68.88, p<0.001\right)$.

No significant difference was found in the monthly growth rate of each sub-cohort between Chicamo and Rambla Salada (Table 2). Groups of youngof-the-year of the 2 populations showed a high monthly growth rate (mean of ca. $32 \%$ ) in both males and females. Males constituting the first (A) and the second (B) sub-cohorts of the year maintained high growth rates up to October, although the mean size $\left(L_{\mathrm{T}}\right)$ reached by the former was greater (Fig. 2). Because of the low growth rate (mean of ca. $3 \%$ ) after this time, individuals had practically the same lengths during the rest of the autumn and winter. In March-April, growth accelerated, especially in subcohort $\mathrm{B}$, and, consequently, the 2 annual sub-cohorts
The growth rate was positively correlated with temperature, although no relation could be detected between growth rate and water salinity or $\mathrm{pH}$ (Table 3).

\section{Somatic and hepatic condition}

The results of the ANCOVAs to estimate the effects of the factors population and season on the $L_{\mathrm{T}}-M_{\mathrm{E}}$ and $L_{\mathrm{T}}-M_{\mathrm{H}}$ relationships showed that population had a significant effect in the preliminary design (test for interaction) in males and females (ANCOVA: p < 0.05). Thus, the 2 populations were analysed separately. Season also had a significant effect on the above relationships in each independent analysis of males and females in Chicamo and Rambla Salada (Table 4).

Significant changes were observed in the temporal variation of the ANCOVA-adjusted $M_{\mathrm{E}}$ and $M_{\mathrm{H}}$ values (somatic and hepatic condition, respectively) for the 2 populations (Table 5). A similar somatic condition cycle was evident in both populations for males (Spearman's correlation of mean values: $\mathrm{r}_{\mathrm{S}}=0.61, \mathrm{p}<$ $0.001)$ and females $\left(r_{S}=0.35, p=0.012\right)$. ANCOVAadjusted $M_{\mathrm{E}}$ values for males were similar in both populations (ANOVA: $F_{1,1738}=1.045 \times 10^{-4}, \mathrm{p}=$ 0.992), whereas the values for females were higher in Rambla Salada $\left(F_{1,1901}=61.68, \mathrm{p}<0.001\right)$. In general, newborn males increased their condition from MayJuly as the reproductive season progressed (Fig. 3). A period of stable condition lasted from November to April-May of the next year, when surviving 1+ males showed a fresh increase in $M_{\mathrm{E}}$ values. Females slightly improved their condition in their first months 

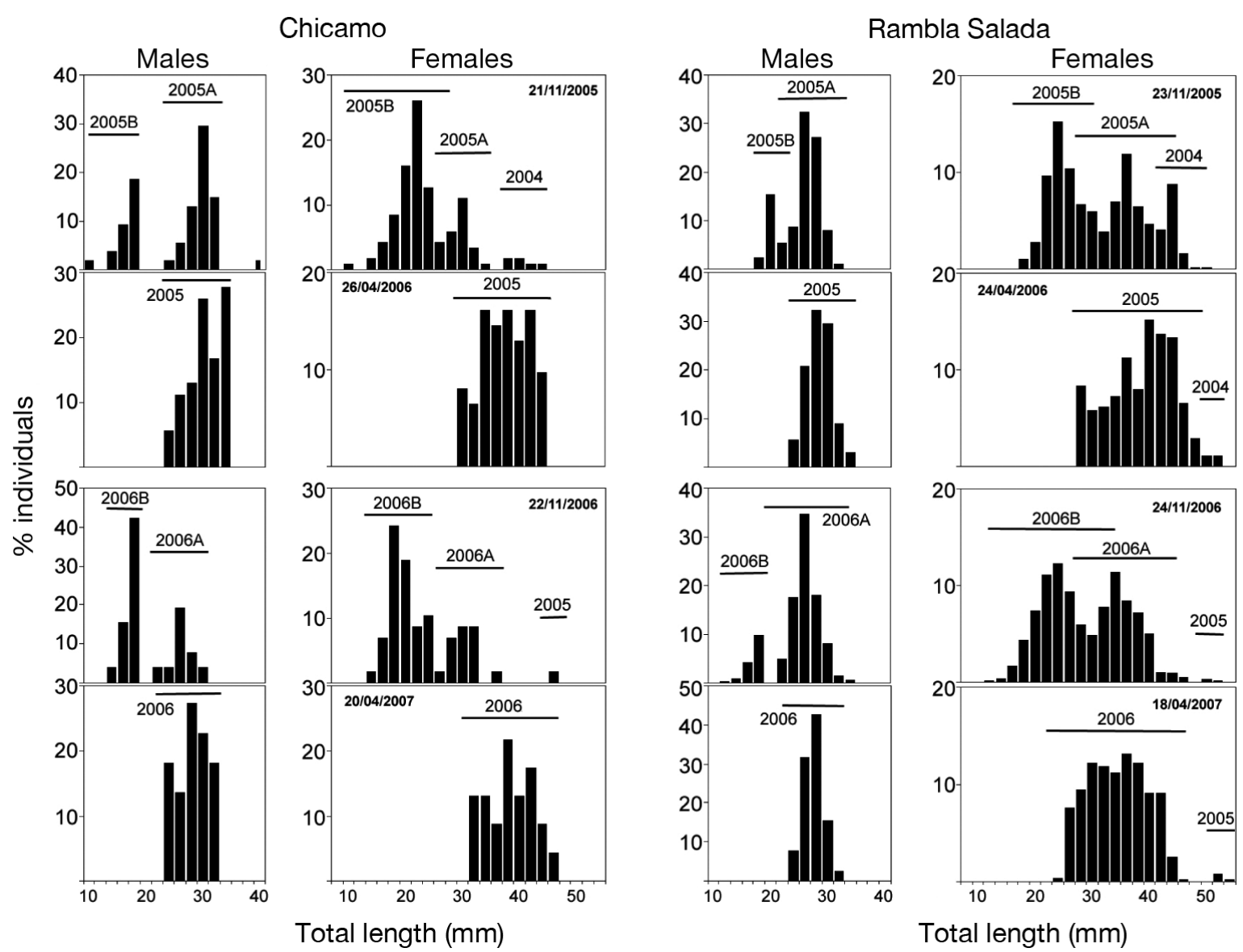

Fig. 2. Gambusia holbrooki. Length-frequency distributions of individuals in November and April at Chicamo and Rambla Salada. Sampling dates are the same for males and females in each population. Juveniles $(<20 \mathrm{~mm}$ total length) are incorporated in both sexes. A and B represent sub-cohorts of the populations

of life, and at the end of the reproductive season no change was registered in $M_{\mathrm{E}}$ values. At the beginning of the next spring, the condition of females underwent a great increase, meaning that females reached higher $M_{\mathrm{E}}$ values than males $\left(F_{1,4417}=1383.92\right.$, $\mathrm{p}<0.001$ ).

The hepatic condition cycle was also similar in both populations for males (Spearman's correlation of mean values: $\left.r_{S}=0.88, p<0.001\right)$ and females $\left(r_{S}=\right.$ $0.39, \mathrm{p}=0.005$ ). However, the ANCOVA-adjusted $M_{\mathrm{H}}$ values were higher in Rambla Salada for males (ANOVA: $F_{1,1735}=440.47, \mathrm{p}<0.001$ ) and females $\left(F_{1,1900}=464.78, \mathrm{p}<0.001\right)$. The hepatic condition of males increased from birth in spring to autumn and then decreased during the winter and following spring (Fig. 3). At the beginning of the summer, a slight increase in hepatic condition was detected before the 1+ males disappeared from the populations. $M_{\mathrm{H}}$ values of females hardly rose during the reproductive season and diminished in winter. A clear increase in hepatic condition was registered from the following March to June, which was maintained until it fell in winter. $M_{\mathrm{H}}$ values were higher for females than for males $\left(F_{1,4414}=2898.56, \mathrm{p}<\right.$ 0.001). The hepatic condition cycle was closely related to somatic condition in males and females (Spearman's correlation: $\mathrm{r}_{\mathrm{S}}=0.88, \mathrm{p}<0.001$ ).

Somatic and hepatic conditions were negatively correlated with salinity, although their relationship with temperature depended on the sex of the individual (Table 3).

\section{DISCUSSION}

The temporal variations of abundance were similar in both populations, characterized by maximum values in autumn, which agrees with most populations studied (Pyke 2008). This cycle is mainly related to the opportunistic strategy, described for Gambusia holbrooki by Vila-Gispert \& Moreno-Amich (2002), as this species presents a massive emergence of 
Table 3. Correlation matrix of growth rate [ $G\left(L_{\mathrm{T}}\right)$, where $L_{\mathrm{T}}$ is total length], somatic condition (ANCOVA-adjusted eviscerated mass) and hepatic condition (ANCOVA-adjusted hepatic mass) of Gambusia holbrooki with environmental variables in 2 populations (Spearman's rank correlation coefficients). Significant differences are indicated: ${ }^{*} \mathrm{p}<0.05{ }_{i}{ }^{* *} \mathrm{p}<0.001$

\begin{tabular}{|c|c|c|c|c|c|}
\hline Population & Variable & Sex & Temperature & Salinity & $\mathrm{pH}$ \\
\hline \multirow[t]{6}{*}{ Chicamo } & \multirow[t]{2}{*}{ Growth rate } & Male & $0.67^{*}$ & -0.23 & 0.01 \\
\hline & & Female & $0.79^{* *}$ & -0.12 & 0.16 \\
\hline & \multirow[t]{2}{*}{ Somatic condition } & Male & $-0.55^{*}$ & $-0.42^{*}$ & -0.02 \\
\hline & & Female & $0.41^{*}$ & $-0.55^{*}$ & 0.27 \\
\hline & \multirow[t]{2}{*}{ Hepatic condition } & Male & $-0.66^{* *}$ & -0.01 & 0.16 \\
\hline & & Female & 0.19 & $-0.63^{*}$ & 0.32 \\
\hline \multirow{6}{*}{$\begin{array}{l}\text { Rambla } \\
\text { Salada }\end{array}$} & \multirow[t]{2}{*}{ Growth rate } & Male & $0.44^{*}$ & -0.07 & -0.19 \\
\hline & & Female & $0.65^{*}$ & -0.11 & -0.08 \\
\hline & \multirow[t]{2}{*}{ Somatic condition } & Male & $-0.45^{*}$ & $-0.63^{* *}$ & -0.01 \\
\hline & & Female & $0.43^{*}$ & $-0.41^{*}$ & 0.21 \\
\hline & \multirow[t]{2}{*}{ Hepatic condition } & Male & $-0.67^{* *}$ & -0.33 & -0.05 \\
\hline & & Female & 0.25 & $-0.54^{*}$ & 0.27 \\
\hline
\end{tabular}

Table 4. Results of ANCOVA analyses of the (a) $L_{\mathrm{T}}-M_{\mathrm{E}}$ and (b) $L_{\mathrm{T}}-M_{\mathrm{H}}$ relationships in Gambusia holbrooki from Chicamo and Rambla Salada. Total length $\left(L_{\mathrm{T}}\right)$ is the covariate. $M_{\mathrm{E}}$ : eviscerated mass; $M_{\mathrm{H}}$ : hepatic mass

\begin{tabular}{|c|c|c|c|c|c|c|}
\hline & $F$ & $\begin{array}{l}\text {-Males } \\
\text { df }\end{array}$ & $\mathrm{p}$ & $F$ & $\begin{array}{c}\text { Females } \\
\text { df }\end{array}$ & $\mathrm{p}$ \\
\hline \multicolumn{7}{|c|}{$\begin{array}{l}\text { (a) } \boldsymbol{L}_{\mathrm{T}}-\boldsymbol{M}_{\mathrm{E}} \\
\text { Chicamo (test for interaction) }\end{array}$} \\
\hline Length & 2642.09 & 1,464 & $<0.001$ & 32901.62 & 1,760 & $<0.001$ \\
\hline Season & 2.91 & 8,464 & 0.004 & 8.31 & 8,760 & $<0.001$ \\
\hline Length $\times$ Season & 2.69 & 8,464 & 0.007 & 6.76 & 8,760 & $<0.001$ \\
\hline \multicolumn{7}{|c|}{ Rambla Salada (test for interaction) } \\
\hline Length & 6465.04 & 1,1574 & $<0.001$ & 47158.87 & 1, 1549 & $<0.001$ \\
\hline Season & 1.97 & 8,1574 & 0.046 & 3.05 & 8,1549 & 0.002 \\
\hline Length $\times$ Season & 2.14 & 8,1574 & 0.030 & 3.06 & 8,1549 & 0.002 \\
\hline \multicolumn{7}{|c|}{$\begin{array}{l}\text { (b) } \boldsymbol{L}_{\mathrm{T}}-\boldsymbol{M}_{\mathrm{H}} \\
\text { Chicamo (test for interaction) }\end{array}$} \\
\hline Length & 128.40 & 1,463 & $<0.001$ & 1510.21 & 1,760 & $<0.001$ \\
\hline Season & 1.48 & 8,463 & 0.161 & 6.62 & 8,760 & $<0.001$ \\
\hline Length $\times$ Season & 1.35 & 8,463 & 0.218 & 6.41 & 8,760 & $<0.001$ \\
\hline \multicolumn{7}{|c|}{ Chicamo (final design) } \\
\hline Length & 257.78 & 1,471 & $<0.001$ & & & \\
\hline Season & 36.43 & 8,471 & $<0.001$ & & & \\
\hline \multicolumn{7}{|c|}{ Rambla Salada (test for interaction) } \\
\hline Length & 314.64 & 1,1572 & $<0.001$ & 3896.17 & 1,1549 & $<0.001$ \\
\hline Season & 3.31 & 8,1572 & 0.001 & 4.67 & 8,1549 & $<0.001$ \\
\hline Length $\times$ Season & 3.15 & 8,1572 & 0.002 & 5.42 & 8,1549 & $<0.001$ \\
\hline
\end{tabular}

holbrooki density peaked at ca. $2 \mathrm{~g} \mathrm{l}^{-1}$. Other environmental factors such as the lower interspecific competition in Rambla Salada and the higher food availability (Guerrero et al. 2004, Gutiérrez-Cánovas et al. 2009) could have been factors facilitating population development and could disguise the direct relationship between salinity and species abundance.

Gambusia spp. populations may also be affected by unpredictable events such as floods and droughts, and dramatic interannual declines associated with sudden changes in habitat characteristics have been observed (Dudley \& Matter 1999, Chapman \& Warburton 2006). In our study, the interannual decrease of $G$. holbrooki abundance in the Chicamo population could be related to the typical annual floods (Vidal-Abarca et al. 2000) (at least 2 during the study period) and their cleaning effect on the fish population. However, 2 other factors help to explain the interannual decrease in G. holbrooki abundance. Firstly, the population size estimated at the beginning of the study period was notably low (summer density in ponds $=8$ to 13 ind $\mathrm{m}^{-2}$; F. OlivaPaterna unpubl. data) in this isolated sector of Chicamo. Secondly, the extraction of individuals from this population during the $2 \mathrm{yr}$ of the study must be considered equally determinant.

In contrast, the Rambla Salada population showed a significant increase in abundance in the second cycle of the study, which was probably directly affected by changes in water salinity as a consequence of the dilution process suffered by the system. Decreases in salinity mean an improve-

young-of-the-year during the recruitment period and high adult mortality, which is related to the somatic costs of reproduction, as well as predation and illness (Fernández-Delgado 1989, Vargas \& de Sostoa 1996). However, total population abundance in the hypersaline Rambla Salada was more than 80 times greater than in the mesosaline Chicamo, which disagrees with data shown in the parabolic relationship presented in Alcaraz \& García-Berthou (2007), where G. ment in environmental conditions for Gambusia spp., not only because of physiological stress and osmoregulation (Plaut 2000, Oliva-Paterna et al. 2007) but also because of associated changes in habitat, mainly higher food availability (Velasco et al. 2006, Gutiérrez-Cánovas et al. 2009). The reproductive characteristics of Gambusia spp. enable numbers to increase very quickly and hence repopulate areas when environmental conditions become suitable (Pyke 2005, 
Table 5. Inter-season comparison of fish condition values [ANCOVA-adjusted eviscerated $\left(M_{\mathrm{E}}\right)$ and hepatic mass $\left(M_{\mathrm{H}}\right)$ ] of Gambusia holbrooki from Chicamo and Rambla Salada by ANOVA and Tukey's honestly significant difference (HSD) test. Aut: autumn; Spr: spring; Sum: summer; Win: winter

\begin{tabular}{|c|c|c|c|c|c|}
\hline & Cohort & \multicolumn{3}{|c|}{ ANOVA- } & Tukey's HSD \\
\hline \multicolumn{6}{|c|}{ (a) ANCOVA-adjusted $M_{\mathrm{E}}$} \\
\hline \multirow{9}{*}{ Chicamo } & Males & & & & \\
\hline & 2005 & 14.76 & 2,152 & $<0.001$ & Aut05 $>$ Win06 $<$ Spr06 \\
\hline & 2006 & 122.45 & 3,206 & $<0.001$ & Sum06 $<$ Aut06=Win07=Spr07 \\
\hline & 2007 & 33.53 & 1,50 & $<0.001$ & Sum07<Aut0 ${ }^{\text {a }}$ \\
\hline & Females & & & & \\
\hline & 2004 & 41.50 & 1,12 & $<0.001$ & Aut05>Win06 ${ }^{\mathrm{a}}$ \\
\hline & 2005 & 40.71 & 4,227 & $<0.001$ & Aut05=Win06 $<$ Spr06 $<$ Sum06 = Win07 \\
\hline & 2006 & 78.58 & 4,396 & $<0.001$ & Sum06=Aut06=Win07 $<$ Spr07 $<$ Sum07 \\
\hline & 2007 & 0.82 & 2,67 & 0.443 & Spr07 $=$ Sum07 $=$ Aut07 \\
\hline \multirow[t]{9}{*}{ Rambla Salada } & Males & & & & \\
\hline & 2005 & 18.62 & 3,272 & $<0.001$ & Aut05=Win06 $<$ Spr06 $<$ Sum06 \\
\hline & 2006 & 127.50 & 5,945 & $<0.001$ & Spr06 $<$ Sum06 $<$ Aut06=Win07=Spr07 $<$ Sum07 \\
\hline & 2007 & 63.15 & 2,315 & $<0.001$ & Spr07 $<$ Sum07 $<$ Aut07 \\
\hline & Females & & & & \\
\hline & 2004 & - & - & - & - \\
\hline & 2005 & 103.52 & 5,284 & $<0.001$ & Aut05 $>$ Win06 $<$ Spr06 $<$ Sum06=Aut06 $>$ Win07 \\
\hline & 2006 & 141.89 & 6,896 & $<0.001$ & Spr06 $=$ Sum06 $=$ Aut06 $=$ Win $07<$ Spr07 $<$ Sum07 $=$ Aut0 7 \\
\hline & 2007 & 18.86 & 2,296 & $<0.001$ & Spr07 $<$ Sum07=Aut07 \\
\hline \multicolumn{6}{|c|}{ (b) ANCOVA-adjusted $M_{H}$} \\
\hline \multirow[t]{9}{*}{ Chicamo } & Males & & & & \\
\hline & 2005 & 65.02 & 2,152 & $<0.001$ & Aut05 $>$ Win06=Spr06 \\
\hline & 2006 & 367.60 & 3,205 & $<0.001$ & Sum06<Aut06>Win07>Spr07 \\
\hline & 2007 & 179.70 & 1,50 & $<0.001$ & Sum07<Aut07a \\
\hline & Females & & & & \\
\hline & 2004 & 58.60 & 1,12 & $<0.001$ & Aut05>Win06 ${ }^{\mathrm{a}}$ \\
\hline & 2005 & 38.44 & 4,227 & $<0.001$ & Aut05 $>$ Win $06<$ Spr06 $<$ Sum06 $=$ Win07 \\
\hline & 2006 & 63.69 & 4,396 & $<0.001$ & Sum06 $<$ Aut06=Win07 $<$ Spr07 $<$ Sum07 \\
\hline & 2007 & 2.42 & 2,67 & 0.097 & Spr07 $=$ Sum07 $=$ Aut 07 \\
\hline \multirow[t]{9}{*}{ Rambla Salada } & Males & & & & \\
\hline & 2005 & 495.59 & 3,270 & $<0.001$ & Aut05>Win06>Spr06<Sum06 \\
\hline & 2006 & 511.50 & 5,945 & $<0.001$ & Spr06 $<$ Sum06 $<$ Aut06 $>$ Win07 $>$ Spr07 $<$ Sum07 \\
\hline & 2007 & 205.45 & 2,315 & $<0.001$ & Spr07 $<$ Sum07 $<$ Aut07 \\
\hline & Females & & & & \\
\hline & 2004 & - & - & - & - \\
\hline & 2005 & 97.70 & 5,284 & $<0.001$ & Aut05 $>$ Win $06<$ Spr06 $<$ Sum06=Aut06=Win 07 \\
\hline & 2006 & 94.46 & 6,897 & $<0.001$ & Spr06=Sum06 $<$ Aut06 $>$ Win $07<$ Spr07 $<$ Sum07 $=$ Aut 07 \\
\hline & 2007 & 4.09 & 2,295 & 0.018 & Spr07 $=$ Sum07 $=$ Aut07 $($ Spr07 $<$ Aut07) \\
\hline
\end{tabular}

2008). Accordingly, the species was 3.9 times more abundant in the period of low salinity (2006-2007, $25.8 \mathrm{~g} \mathrm{l}^{-1}$ ) than in the period of high salinity (20052006, $43.5 \mathrm{~g} \mathrm{l}^{-1}$ ). In addition, in the first recruitment period, fish abundance reached a maximum in autumn, reflecting the general pattern of the species. However, in the second year, abundance increased in summer but then decreased in the following autumn, coinciding with a registered salinity increase.

The effect of salinity on the survival of Gambusia holbrooki was studied in a freshwater population by Nordlie \& Mirandi (1996), who found that environ- ment salinities of up to $15 \mathrm{~g} \mathrm{l}^{-1}$ were not severely restrictive, although salinity above this level resulted in increasing mortality. The closely related species G. affinis is, in general, able to tolerate gradual increases of salinity up to $39 \mathrm{~g} \mathrm{l}^{-1}$, although mortality is $35 \%$ higher in such conditions (Chervinski 1983). However, it seems likely that a Gambusia spp. population that has long been exposed to harsh environmental conditions would be able to adapt to a gradual increase in hostile environmental conditions (e.g. salinity) (Hubbs 2000). Even so, minor salinityinduced mortality may operate differentially on 

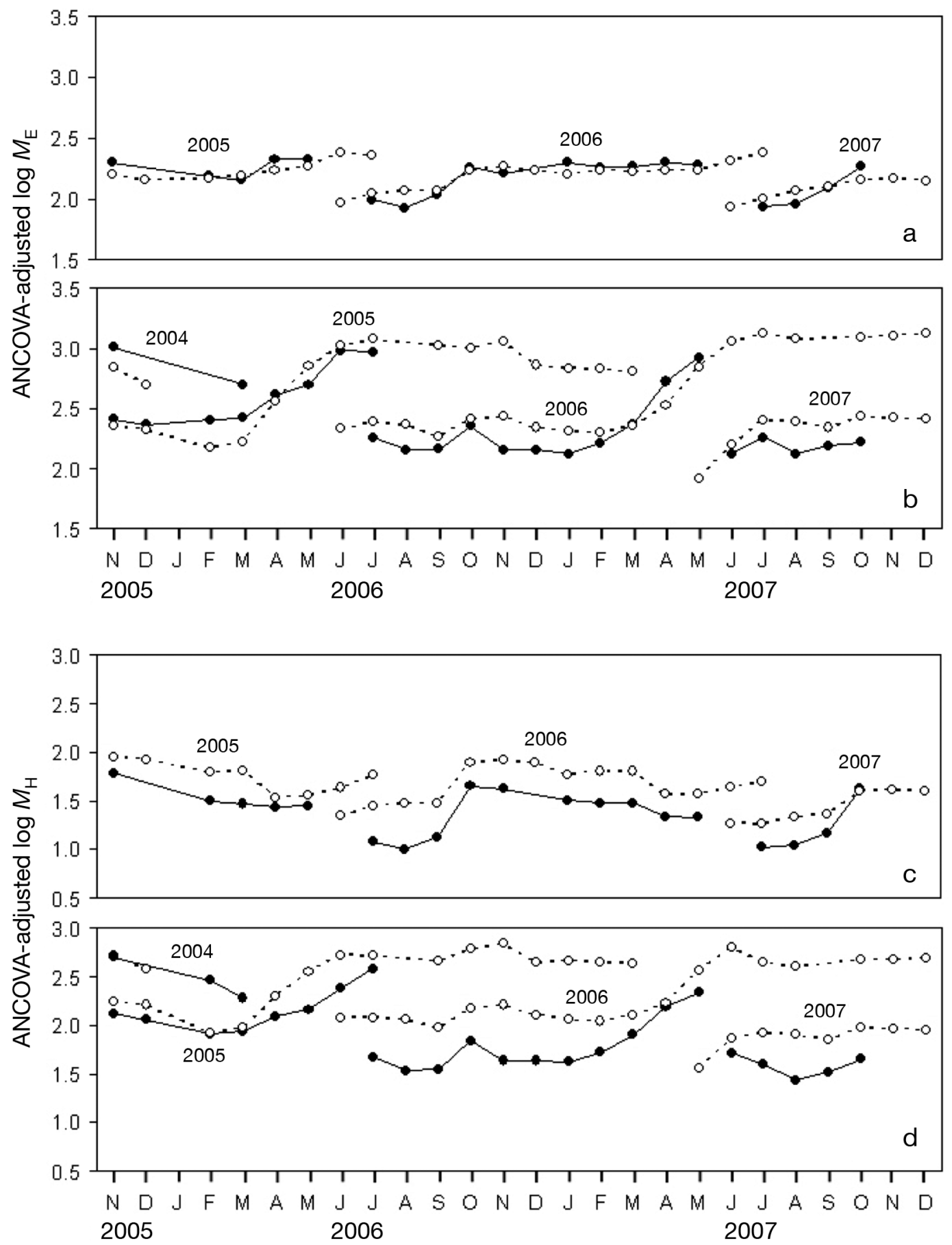

Fig. 3. Gambusia holbrooki. Temporal variation in somatic and hepatic condition of G. holbrooki from Chicamo (filled circles) and Rambla Salada (open circles) based on the monthly means of ANCOVA-adjusted eviscerated $\left(M_{\mathrm{E}}\right)$ and hepatic $\left(M_{\mathrm{H}}\right)$ mass values for samples of a minimum of 4 fish. $(\mathrm{a}, \mathrm{b})$ Somatic condition for males and females, respectively; (c,d) hepatic condition for males and females, respectively

genetically different populations (Congdon 1994, Kandl \& Thompson 1996). The clear viability of the $G$. holbrooki population inhabiting Rambla Salada supports these hypotheses. Nevertheless, the abundance of individuals seems to respond quite clearly to salin- ity variations. Thus, abundance of this species could be a useful indicator of the loss of natural conditions in this stream through dilution stress, in the same way as the biomass of the epipelic alga Cladophora glomerata (Gutiérrez-Cánovas et al. 2009). 
Both populations showed an age structure similar to those described for other populations of the species in different habitats from the Iberian Peninsula (Pérez-Bote \& López 2005, Tedesco et al. 2008). The investment of great amounts of energy for rapid growth and reproduction could lead to the death of 1+ spawners after reproduction (Fernández-Delgado 1989). However, Gambusia spp. males seem more susceptible to hypoxia, temperature stress, overcrowding, winter conditions and the diminution of environmental resources than females, and they generally do not live long after reaching maturity (Haynes \& Cashner 1995). A similar population structure of $G$. holbrooki inhabiting watercourses of different degrees of salinity has already been shown by Alcaraz \& García-Berthou (2007), although the present study extends the salinity range studied in a natural population up to $49.5 \mathrm{~g} \mathrm{l}^{-1}$. These results point to the good adaptation of the species to environments of different quality (Specziár 2004), as has been described for $G$. affinis (Brown-Peterson \& Peterson 1990).

Despite the high degree of size group overlapping within the $0+$ age class, 2 new sub-cohorts of individuals were differentiated each year, the first including the individuals born at the beginning of the recruitment period and the second including the offspring born during the last months of the period. Other studies (Cabral \& Marques 1999, Pérez-Bote \& López 2005) point to this high degree of overlapping, whereas in our study the existence of 2 significantly different sub-cohorts within 0+ was confirmed.

The recruitment period was long, lasting from May to August-September in Rambla Salada and extending to November in Chicamo, thus fitting the general pattern demostrated by the species (Milton \& Arthington 1983). However, the recruitment period partly differs from that of other populations studied in the Iberian Peninsula, such as those in the Ebro Delta (Vargas \& de Sostoa 1996), Zoñar lagoon (Fernández-Delgado \& Rossomanno 1997) and Mondego River Valley (Cabral \& Marques 1999), in which recruitment lasted from June to October. The reproductive period of Gambusia species and, therefore, recruitment extension, are mainly controlled by photoperiod and temperature (e.g. Haynes \& Cashner 1995, Koya \& Kamiya 2000), which could explain the small differences detected from other populations of the species. Differences in the extension of the recruitment period found between our 2 populations cannot be assigned to differences in photoperiod or temperature. However, salinity can be affecting this extension, as a shorter recruitment period in saltier habitats has been previously described in G. affinis (Brown-Peterson \& Peterson 1990). But salinity also affected recruitment intensity: it was clearly higher in Chicamo than in Rambla Salada, and in the latter population, when salinity was higher, recruitment intensity was lower. High salinity is an important stress factor in cyprinodontiform survival, especially in larval stages or juveniles (Bohlen 1999, OlivaPaterna et al. 2009). However, other ecological and social factors could also influence recruitment (e.g. Myers 2002).

Both studied populations were characterized by fast growth from March-April to autumn, and this period is clearly longer than those observed in other Iberian populations (Vargas \& de Sostoa 1996, PérezBote \& López 2005). The high growth rate of young individuals favours their survival, as the advantages of larger size include greater feeding capacity and avoidance of predation (Reznick 1983). Moreover, achieving a minimum size before cold months might be important for overwinter survival (Reznick \& Braun 1987).

The somatic condition cycles of males and females were similar in both the Chicamo and Rambla Salada populations, and the general pattern was also similar to previously studied populations (e.g. Vargas \& de Sostoa 1996, Pérez-Bote \& López 2005). Males quickly increased their somatic condition from birth up to October, allowing them to reach sexual maturity and reproduce in the same reproductive season (Fernández-Delgado 1989). Females presented a moderate increase in condition during their first spring-summer and a stability or decrease in autumn and winter, probably because of the assignment of energy and resources to reproduction (Reznick \& Braun 1987). After a period of somatic condition stability during the cold months, overwintering individuals showed a new increase in this parameter. This was earlier and faster in females, leading to higher average condition values than males. From July onwards, because of extreme reproductive effort (Reznick et al. 2006), most 1+ individuals died after reproduction and the rest were only able to maintain their condition until winter.

Alcaraz \& García-Berthou (2007) observed that the somatic condition of Gambusia holbrooki females was lower in populations in high salinity conditions. Although a negative correlation between salinity and somatic condition values is clear from the present study, females in Rambla Salada presented higher somatic condition values than those in Chicamo. This might have been the result of other environmental factors not considered in the present study, such as 
competition, food availability or prey nutritional content (Pyke 2005). In addition, the allotment of energy to reproduction could also be an important factor influencing somatic condition (Meffe \& Snelson 1993). To analyse these factors in depth, specific studies should be carried out.

The same pattern of hepatic condition variation was observed in Chicamo and Rambla Salada for both sexes. In females, contrary to males, this parameter increased only moderately, probably as a result of high reproductive effort, as has been described for other species (Andreu-Soler et al. 2006). After reaching a maximum in October-November, hepatic condition suffered a decrease similar to that of males. Although individuals from Rambla Salada presented a heavier liver, a negative correlation between salinity and hepatic condition appeared in female Gambusia holbrooki. Higher hepatic lipid content in saltier environments has been previously described for other euryhaline fish species (Craig et al. 1995). A possible explanation is that individuals inhabiting saltier waters need to increase the accumulation of fatty acid providers, used in increasing membrane permeability for ionic transfer (Bell et al. 1986). In contrast, a decrease in the lipid content of liver in poeciliids that are adapting to more saline waters has also been described (Daikoku et al. 1982).

In conclusion, in the 2 semiarid, saline streams studied, Gambusia holbrooki showed a similar lifehistory strategy to that of other freshwater populations. However, some differences detected between the populations could be related to environmental stress produced by salinity. The life-history traits analysed show that $G$. holbrooki presents a clear ability to adapt to lotic systems with high and very variable salinity. Thus, it is not clear that high salinity prevents its invasive success.

Acknowledgements. We thank D. Verdiell-Cubedo, A. Andreu-Soler, A. V. García-Lacunza and J. Caravaca for help in field and laboratory work and P. Thomas for English revision of the manuscript. We also thank E. García-Berthou and anonymous reviewers for their valuable comments that greatly improved the manuscript. Financial support was provided by a LIFE-Nature project (LIFE04NAT/ES/00035) and the Environmental Service of Autonomous Government of Murcia, Spain. A.R.-N. held a doctoral fellowship (FPU AP2006-01528) from the Spanish Ministry of Education.

\section{LITERATURE CITED}

> Alcaraz C, García-Berthou E (2007) Life history variation of invasive mosquitofish (Gambusia holbrooki) along a salinity gradient. Biol Conserv 139:83-92

Alcaraz C, Bisazza A, García-Berthou E (2008) Salinity mediates the competitive interactions between invasive mosquitofish and an endangered fish. Oecologia 155: 205-213

Andreu-Soler A, Oliva-Paterna FJ, Torralva M (2006) Seasonal variations in somatic condition, hepatic and gonad activity of sand smelt Atherina boyeri (Teleostei, Atherinidae) in the Mar Menor coastal lagoon (SE Iberian Peninsula). Folia Zool (Brno) 55:151-161

Beaudouin R, Ginot V, Monod G (2008) Growth characteristics of eastern mosquitofish Gambusia holbrooki in a northern habitat (Brittany, France). J Fish Biol 73: 2468-2484

Bell MV, Henderson RJ, Sargen JR (1986) The role of polyunsaturated fatty acids in fish. Comp Biochem Physiol 83B:711-719

Bhattacharya CG (1967) A simple method of resolution of a distribution into Gaussian components. Biometrics 23: 115-135

Bohlen J (1999) Influence of salinity on early development in the spined loach. J Fish Biol 55:189-198

Brown-Peterson N, Peterson MS (1990) Comparative lifehistory of female mosquitofish, Gambusia affinis, in tidal freshwater and oligohaline habitats. Environ Biol Fishes 27:33-41

> Cabral JA, Marques JC (1999) Life history, population dynamics and production of eastern mosquitofish, Gambusia holbrooki (Pisces, Poeciliidae), in rice fields of the lower Mondego River Valley, western Portugal. Acta Oecol 20:607-620

Chapman CP, Warburton K (2006) Postflood movements and population connectivity in gambusia (Gambusia holbrooki). Ecol Freshw Fish 15:357-365

> Chervinski J (1983) Salinity tolerance of the mosquito fish, Gambusia affinis (Baird \& Girard). J Fish Biol 22:9-11

> Congdon BC (1994) Salinity-related fitness differences amongst GPI genotypes in the mosquitofish Gambusia holbrooki (Poeciliidae: Teleostei). Biol J Linn Soc 53: 343-352

Cowardin LM, Carter V, Golet FC, LaRoe ET (1979) Classification of wetlands and deepwater habitats of the United States. US Department of the Interior, Fish and Wildlife Service, Washington, DC

> Craig SR, Neill WH, Gatlin DM (1995) Effects of dietary lipid and environmental salinity on growth, body composition, and cold tolerance of juvenile red drum (Sciaenops ocellatus). Fish Physiol Biochem 14:49-61

> Daikoku T, Yano I, Masui M (1982) Lipid and fatty acid compositions and their changes in the different organs and tissues of guppy, Poecilia reticulata on sea water adaptation. Comp Biochem Physiol A 73:167-174

Doadrio I (ed) (2002) Atlas y libro rojo de los peces continentales de España. CSIC y Ministerio de Medio Ambiente, Madrid

Dudley RK, Matter WJ (1999) Effects of a record flood on fishes in Sabino Creek, Arizona. Southwest Nat 44: $218-221$

> Fernández-Delgado C (1989) Life-history patterns of the mosquitofish, Gambusia affinis, in the estuary of the Guadalquivir River of south-west Spain. Freshw Biol 22:395-404

> Fernández-Delgado C, Rossomanno S (1997) Reproductive biology of the mosquitofish in a permanent natural lagoon in south-west Spain: two tactics for one species. J Fish Biol 51:80-92

Gayanilo FC, Soriano M, Pauly D (1988) A draft guide to the Complete ELEFAN. ICLARM Software 2. International 
Center for Living Aquatic Resources Management, Manila

Guerrero C, Vidal-Abarca MR, Suárez ML, Gómez R, Ortega M (2004) Estructura de tamaño de la comunidad de macroinvertebrados acuáticos en un río de características semiáridas durante el estiaje (río Chícamo, SE España). Limnetica 23:37-56 (In Spanish with English Abstract)

> Gutiérrez-Cánovas C, Velasco J, Millán A (2009) Effects of dilution stress on the functioning of a saline Mediterranean stream. Hydrobiologia 619:119-132

Haynes JL, Cashner RC (1995) Life history and population dynamics of the western mosquitofish: a comparison of natural and introduced populations. J Fish Biol 46:1026-1041

Hubbs C (2000) Survival of Gambusia affinis in a hostile environment. Southwest Nat 45:521-522

Kandl KL, Thompson AJ (1996) Responses of eastern mosquitofish (Gambusia holbrooki) to acute salinity stress: Do family effects obscure inbreeding and genotype effects? Can J Fish Aquat Sci 53:753-760

> Koya Y, Kamiya E (2000) Environmental regulation of annual reproductive cycle in the mosquitofish, Gambusia affinis. J Exp Zool 286:204-211

Lowe S, Browne M, Boudjelas S, De Poorter M (2000) 100 of the world's worst invasive alien species. A selection from the Global Invasive Species Database. Invasive Species Specialist Group, Auckland

Martínez B, Velasco J, Suárez ML, Vidal-Abarca MR (1998) Benthic organic matter dynamics in an intermittent stream in south-east Spain. Arch Hydrobiol 141:303-320

Meffe GK, Snelson FF Jr (1993) Annual lipid cycle in eastern mosquitofish (Gambusia holbrooki: Poeciliidae) from South Carolina. Copeia 1993:596-604

Milton DA, Arthington AH (1983) Reproductive biology of Gambusia affinis holbrooki Baird and Girard, Xiphophorus helleri (Günther) and X. maculatus (Heckel) (Pisces; Poeciliidae) in Queensland, Australia. J Fish Biol 23:23-41

Myers RA (2002) Recruitment: understanding densitydependence in fish populations. In: Hart PJB, Reynolds JD (eds) Handbook of fish biology and fisheries, Vol 1. Blackwell Science, Oxford, p. 123-148

- Nordlie FG, Mirandi A (1996) Salinity relationships in a freshwater population of eastern mosquitofish. J Fish Biol 49:1226-1232

Oliva-Paterna FJ, García-Alonso J, Cardozo V, Torralva M (2007) Field studies of ammonia excretion in Aphanius iberus (Pisces; Cyprinodontidae): body size and habitat effects. J Appl Ichthyology 23:93-98

> Oliva-Paterna FJ, Ruiz-Navarro A, Torralva M, FernándezDelgado C (2009) Biology of the endangered cyprinodontid Aphanius iberus in a saline wetland (SE Iberian Peninsula). Ital J Zool 76:316-329

Pérez-Bote JL, López MT (2005) Life-history pattern of the introduced eastern mosquitofish, Gambusia holbrooki (Baird \& Girard, 1854), in a Mediterranean-type river: the River Guadiana (SW Iberian Peninsula). Ital J Zool 72:241-248

Plaut I (2000) Resting metabolic rate, critical swimming speed, and routine activity of the euryhaline Cyprinodontid, Aphanius dispar, acclimated to a wide range of salinities. Physiol Biochem Zool 73:590-596

Editorial responsibility: Asbjørn Vøllestad, Oslo, Norway
Pyke G (2005) A review of the biology of Gambusia affinis and G. holbrooki. Rev Fish Biol Fish 15:339-365

Pyke G (2008) Plague minnow or mosquito fish? A review of the biology and impacts of introduced Gambusia species. Annu Rev Ecol Evol Syst 39:171-191

Reznick D (1983) The structure of guppy life histories: the tradeoff between growth and reproduction. Ecology 64 : 862-873

Reznick D, Braun B (1987) Fat cycling in the mosquitofish (Gambusia affinis): fat storage as a reproductive adaptation. Oecologia 73:401-413

> Reznick D, Schultz E, Morey S, Roff D (2006) On the virtue of being the first born: the influence of date of birth on fitness in the mosquitofish, Gambusia affinis. Oikos 114: 135-147

Ribeiro F, Elvira B, Collares-Pereira MJ, Moyle PB (2008) Life-history traits of non-native fishes in Iberian watersheds across several invasion stages: a first approach. Biol Invasions 10:89-102

Rice WR, Sax DF (2005) Testing fundamental evolutionary questions at large spatial and demographic scales: species invasions as an underappreciated tool. In: Sax DF, Stachowicz JJ, Gaines SD (eds) Species invasions: insights into ecology, evolution, and biogeography. Sinauer Associates, Sunderland, MA, p 291-308

Specziár A (2004) Life history pattern and feeding ecology of the introduced eastern mosquitofish, Gambusia holbrooki, in a thermal spa under temperate climate, of Lake Heviz, Hungary. Hydrobiologia 522:249-260

Tedesco PA, Benito J, García-Berthou E (2008) Sizeindependent age effects on reproductive effort in a small, short-lived fish. Freshw Biol 53:865-871

> Vargas MJ, de Sostoa A (1996) Life history of Gambusia holbrooki (Pisces, Poeciliidae) in the Ebro delta (NE Iberian peninsula). Hydrobiologia 341:215-224

- Velasco J, Millán A, Vidal-Abarca MR, Suárez ML, Guerrero C, Ortega M (2003) Macrophytic, epipelic and epilithic primary production in a semiarid Mediterranean stream. Freshw Biol 48:1408-1420

> Velasco J, Millán A, Hernández J, Gutiérrez C, Abellán P, Sánchez D, Ruiz M (2006) Response of biotic communities to salinity changes in a Mediterranean hypersaline stream. Saline Syst 2:12

Vidal-Abarca MR, Montes C, Suárez ML, Ramírez-Díaz L (1990) Sectorización ecológica de cuencas fluviales: aplicación a la cuenca del río Segura (SE España). An Geogr Univ Complut 10:149-182 (In Spanish with English Abstract)

Vidal-Abarca MR, Suárez ML, Ramírez-Díaz L (1992) Ecology of Spanish semiarid streams. Limnetica 8:151-160

Vidal-Abarca MR, Suárez ML, Moreno JL, Gómez R, Sánchez I (2000) Hidroquímica de un río de características semiáridas (río Chicamo, Murcia). Análisis espaciotemporal. Limnetica 18:57-73 (In Spanish with English Abstract)

- Vila-Gispert A, Moreno-Amich R (2002) Life-history patterns of 25 species from European freshwater fish communities. Environ Biol Fishes 65:387-400

Wootton RJ (1998) Ecology of teleost fishes. Kluwer Academic Publishers, Dordrecht

Submitted: November 12, 2010; Accepted: June 9, 2011

Proofs received from author(s): August 19, 2011 